\title{
THE ROLE OF LOCAL GOVERNANCE IN THE PROCESS OF BROWNFIELD REGENERATION: EUROPEAN PLANNING PRACTICE
}

\section{A B S T R A C T}

Because a large number of participants with various interests in the process of brownfield regeneration increase the complexity of the process itself, it is interesting to observe the nature of their collaboration. The focus of this paper is on the role of the local authorities as one of the key stakeholders responsible for the success of brownfield regeneration. Their position and the instruments they use in such a process can be elucidated by observing the organisation of the planning process, the negotiation and decision-making procedures, and the means of conflict resolution. Two European case studies on brownfield regeneration form the empirical research scope of this paper: A former cable and wire factory in Vienna and a former Roma settlement in Budapest. The paper provides an insight into possibilities for a redefinition of planning culture through innovative and proactive planning approaches to brownfield regeneration. 


\section{INTRODUCTION}

The importance of brownfield regeneration for sustainable spatial development has been the focus of many planning debates in recent years. ${ }^{1}$ The implementation of the sustainability principle in contemporary planning practice has resulted in a trend towards brownfield regeneration: "the redevelopment of land or premises which has previously been used or developed and is not currently fully in use". ${ }^{2}$ The immediate reuse of brownfields is not possible without an intervention that involves a wide range of various instruments: planning, social, political, economic, environmental, etc., all of which raise the complexity of the brownfield redevelopment process. However, as the results of the planning phase are crucial for the success of the entire brownfield regeneration cycle, ${ }^{3}$ we can assume that complex spatial problems, such as brownfield regeneration, demand different ways of thinking, and thus different ways of planning from what is considered the traditional decision-making model. ${ }^{4}$

Keeping changes to a planning approach for challenging spatial problems in mind, there are three main aspects that need to be considered in relation to brownfield regeneration: ${ }^{5}$

1. Identifying an adequate planning expertise position,

2. Institutionalising the informal planning procedures, which creates

3. A strong demand for elucidating the roles of various stakeholders and the means of coordinated collaboration.

Placing emphasis on collaboration among a number of stakeholders, we need to be aware of the following demands: ${ }^{6}$

- In order to harmonise various interests, a collaboration between different sectors (public, private and civil) is needed.

- In order to create a synergy of the various knowledge and skills, an integration of expert knowledge is needed, which stems from manifold disciplines, such as urban planning, environment, transport, economy, sociology, as well as empirical knowledge, and which is based on practical experience in the field of brownfield regeneration.

Previous demands led towards focusing on the role of local authorities in the brownfield redevelopment process and their contribution to its success. Local governance holds particular importance in brownfield regeneration for two reasons. Firstly, it plays a major role in a smooth vertical collaboration in a bottom-up process. Local authorities serve as conveyors of ideas created at the local level towards their approval at higher governance levels (regional and 
national). This is particularly true for brownfield redevelopment initiatives, as the topic of brownfields usually goes beyond local significance, i.e. brownfield regeneration is of regional and, often, national importance.

Secondly, local authorities have the role of mediator between the private and civil sector representatives in the process of brownfield revitalisation. Local governance has the role of 'bridging the gap' among numerous demands represented by private investors, pursuing its own, mostly financial, interests on one side, and by the local community, mainly focused on the topic of identity and the preservation of local values on the other. A balance between these two sectors is usually difficult to achieve, in particular, under transitional social circumstances. ${ }^{7}$ Hence, the local government with its specific powers and position within a broader institutional, i.e. a public context, has a critical role.

The paper presents the process of testing the following hypothesis: The participation of local authorities in an innovative and proactive manner contributes to a more effective and efficient brownfield regeneration process. In other words, the paper will report on the role of local government during various phases of the brownfield redevelopment process, their relationship to both the private and civil sectors as well as their relationship to higher governance levels. In addition, the specific skills and knowledge and the type of power used in pursuing public interest are covered.

The paper is structured as follows. After general introductory remarks on the research subject, i.e. the roles, responsibilities and instruments of local governance in the process of brownfield regeneration, the article describes the normative aspects of a collaborative planning model, i.e. the preferred means of collaboration as well as optimal institutional cooperative arrangements, as broadly discussed topics in the body of literature related to brownfield redevelopment. It goes on to present the practice of brownfield revitalisation in two Central European cities, Vienna and Budapest, as its territorial scope. The focus is on elucidating the collaborative planning process through the two case studies, with particular attention on the aspects of the process initiation, its management, negotiation procedures and conflict resolution. A brief discussion of the context-specific response to the problem of brownfield regeneration is given before the final conclusion. 


\section{A COLLABORATIVE PLANNING PARADIGM:}

\section{A BACKGROUND OF PLANNING PRACTICE}

In addition to various instruments, e.g. change of ownership structure, physical or chemical remediation of land and objects, change of planning policy, and marketing measures, the basic condition for an efficient and effective brownfield regeneration process is the quality of the collaboration among its participants. As a simplified scheme of stakeholder collaboration in a brownfield redevelopment process used 14 participants, ${ }^{8}$ the specificity of such a process stems from the number of stakeholders involved, e.g. their various levels of knowledge, skills and power, and, thus the difficulties in achieving compliance among the various, and often, confrontational interests. ${ }^{9}$

Hence, the growing coordination of numerous stakeholders and the institutional reform, through the establishment of legal, policy and knowledge structures, play a crucial role in coping with the problem of brownfield regeneration. ${ }^{10}$ As brownfield regeneration should be carried out according to the premises of the collaborative planning model,,$^{11}$ the interrelated normative aspects of 1) preferred means of collaboration, and 2) optimal institutional arrangements, which are deeply embedded in the doctrine of collaborative planning and closely refer to the notion of local governance (as a research subject), are clarified in the following section.

\section{Achieving effective collaboration}

In narrow terms, the role of local government in the brownfield regeneration process is not only that of monitoring the entire process of zoning, planning and adopting suggested solutions, but also of the control of various interests represented by different departments within its administrative structure. ${ }^{12}$ Moreover, local authorities are responsible for creating a democratic environment where all the stakeholders have a say in the process of identifying a common solution. ${ }^{13}$ In order to achieve a so-called 'win-win' solution, i.e. an ultimate outcome that satisfies everyone, ${ }^{14}$ the planning communication must be directed towards the public, meaning that all the participants in the process must be aware of the attitudes of other parties, while at the same time striving to persuade others of their own attitudes, interests ${ }^{15}$ and values. ${ }^{16}$ This kind of communication is based on individual creativity to a large extent. However, the essence of interactive communication is to achieve cooperativeness, rather than mutual outwitting and competitiveness. Only in this way, can the participants in the process exchange experiences, and then modify their own goals and means in relation to those proposed at the very beginning of the process. Hence, the gist 
of the entire process of unfettered communication is to achieve a consensus, ${ }^{17} \mathrm{a}$ decision acceptable for all the participants in the process.

It is important that all relevant stakeholders participate in the process, and not only those who can easily manipulate the interests, e.g. governance structures. In other words, as collaborative planning has a distinctive approach - one that includes communication among the stakeholders belonging to different social worlds $^{18}$ - all the members of the community should have the opportunity to express their own views and participate actively in decision-making, regardless of what level of power they possess. Such an approach includes the creation of a strategy based on a 'soft infrastructure', in which the behaviours of actors induce certain ways of communicating, interacting and managing. The parameters that enable the collaborative planning process are the following: ${ }^{19}$

- Cooperation and a focus on social relationships, consensus-building and gaining trust among the stakeholders

- Emphasis on the 'practical awareness and local capabilities', as well as on scientific and technical knowledge - without giving privilege to 'rationality'

- Building an interactive consensus based on different interests among the stakeholders

Keeping the subject of this paper in mind, the previously mentioned premises of collaborative planning are significant because they emphasise 'local knowledge' and 'local skills', regulated by the appropriate institutional framework, i.e. local government, which should facilitate decision-making based on local values. Consensus-building is based on openness and trust, while the collaborative network actively transmits knowledge and removes obstacles in the communication process, opens dialogue and eliminates misunderstandings as one of the causes of conflict.

\section{Optimal institutional arrangements}

Building collaborative consensus also requires using a 'bottom-up' approach, which criticises the deductive model of determining values and setting goals. Thus, in order to adequately treat the problem of brownfield regeneration, there is a need for an efficient organisation of public institutions..$^{20}$ More precisely, although local governments take a leading role in the process of brownfield redevelopment, the national government should provide an administrative framework for supporting local initiatives in a brownfield regeneration process. However, achieving adequate vertical coordination between the levels of national, regional and local government remains the main challenge. 
The establishment and preservation of a consensus among the different stakeholders cannot be independent of the 'hard infrastructure' - the socioeconomic system and the key power ${ }^{21}$ holders. ${ }^{22}$ Thus, the critical parameters that enable a collaborative planning process are: ${ }^{23}$

- Recognising the abundance of and differences among stakeholders, as well as the complex relationships that may arise between them, as well as within them

- Recognition of the fact that many activities, usually exclusive to the domain of public administration, can also be performed outside of these institutions

- Supporting the participation of all members of political organisations, while recognising their fundamental differences

These parameters highlight the need for a clear determination of the jurisdiction of governmental organisations, experts, and other institutions, in addition to their mutual cooperation. More precisely, one of the basic forms of adaptation of an institutional organisation to a collaborative planning model is the decentralisation of decision-making, as well as the implementation of planning policies. ${ }^{24}$ Therefore, it is important to strengthen vertical coordination to ensure the harmonisation of decisions made on different government levels (national, regional and local). Furthermore, compliance at the horizontal level of coordination, i.e. finding agreement on the planning policies and decisions made among different sectors and disciplines, is considered a necessary prerequisite of an efficient collaborative planning process. Finally, in addition to cooperation among the same sectors at different government levels, great attention should be placed on cooperation between formal and informal institutions.

\section{COLLABORATIVE PLANNING IN BROWNFIELD REGENERATION PROCESSES: EUROPEAN EXPERIENCES}

The data used to examine the nature of collaboration in the cases of Austria and Hungary were collected through:

1. A content analysis of secondary sources on Austrian ${ }^{25}$ and Hungarian ${ }^{26}$ brownfield regeneration examples, and

2. The semi-structured interviews conducted among key stakeholders who directly participated in the process of brownfield regeneration in Vienna and Budapest. ${ }^{27}$

Therefore, the actors selected for the interviews were experienced planning professionals in the public sector (i.e. local government). Thus, intensity sampling ${ }^{28}$ as one of the methods particularly used for the case study research 
was considered an appropriate method for this paper. The data analysis is presented according to the following structure:

- Initiation of the brownfield regeneration process

- Organisation and management of the planning process

- Negotiation process and decision-making procedures

- Conflict resolution

Such an approach was also used during interviews conducted with the planning professionals. In this way, it is possible to attain a critical overview on stakeholder collaboration and cooperation arrangements. The relationship between the nature of the cooperation and its dependence on the concrete planning context will be discussed in section 4 of this paper.

\section{Former cable and wire factory: KDAG, Vienna}

The first 'good practice' example of brownfield regeneration is the former cable and wire factory (Kabel- und Drahtwerke $A G$ - KDAG) in Vienna, located in municipal District XII of Meidling, in an area of almost seven hectares. ${ }^{29}$ For the entire $20^{\text {th }}$ century, the factory was a prosperous enterprise with several hundred employees. In 1989 during a course of privatisation, the company was sold and consequently started to weaken (Figure 1). Finally, the plant was closed in 1997 and a year later sold to a union of eight developers, who bought not only the building, but also the land where the old factory was situated. ${ }^{30}$

\section{Initiation of the brownfield regeneration process}

The factory had a specific impact on the entire district - not only on its previous employees, but also as a very special identity reference for the local population. Hence, the governance of the City of Vienna, as the initiator of the site redevelopment process, decided on an intensive involvement of the previous workers as well as the local inhabitants. They invited the laid-off staff and local residents to participate in a competition to provide any kind of suggestions (in oral, written or sketch form) for future site development. The jury intentionally did not include urban planners, instead, the Chairman of the District XII office, the local parish priest, a journalist, and representatives of the City of Vienna were chosen to select the three top entries. This was proof that city governance "recognised and appreciated local skills and knowledge." 31 Moreover, the role of the local community was not limited to proposing solutions for the future development of their surroundings: three (out of 30) applicants were chosen as delegates to the Citizens' Advisory Board - the body responsible for monitoring the planning process. 


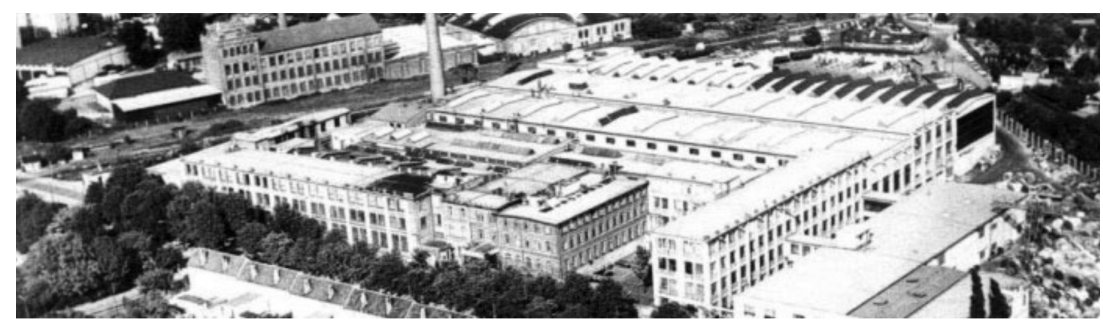

Figure 1. KDAG - cable and wire factory in Vienna. (Source: Buchner, Kohoutek and Pamer, Kabelwerk)

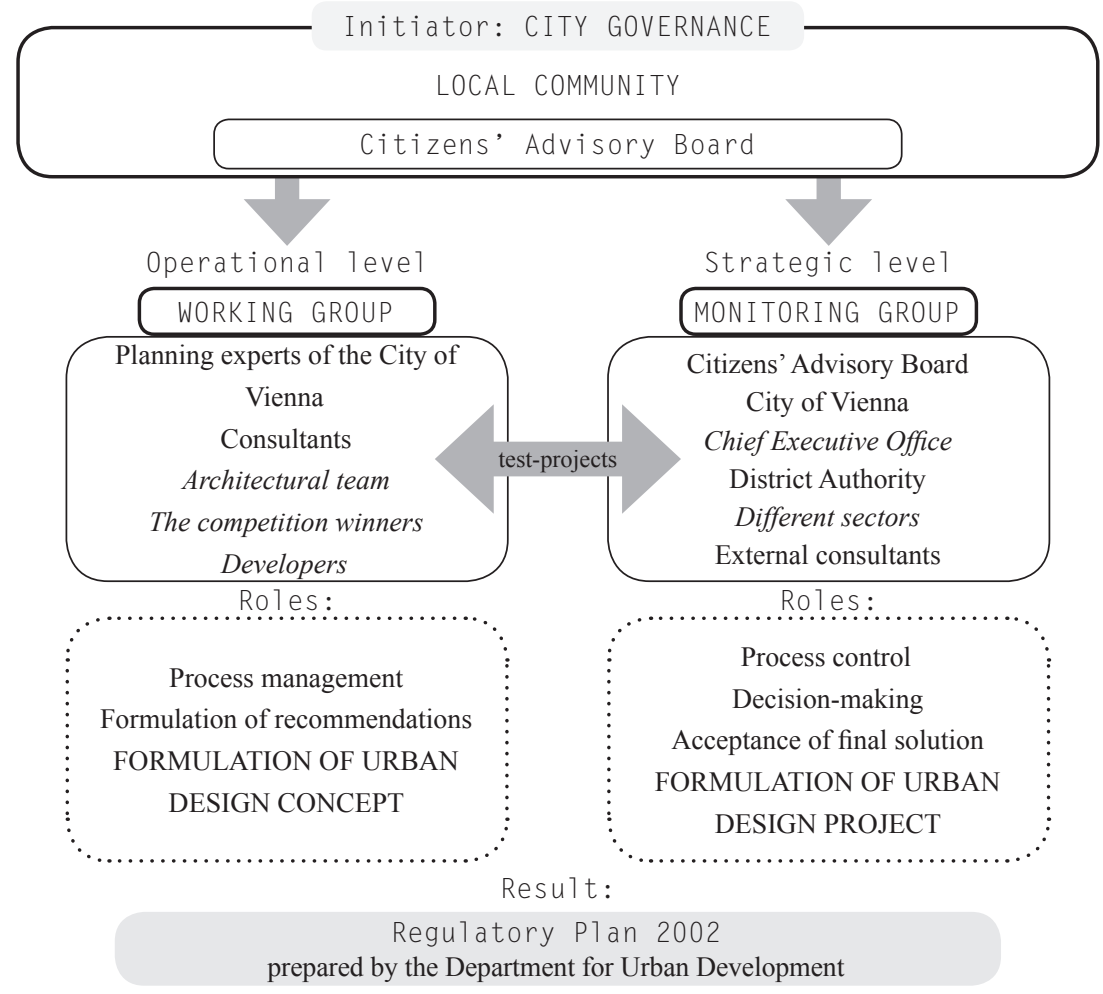

Figure 2. The structure of the brownfield regeneration process in Vienna, Austria. (Source: Author)
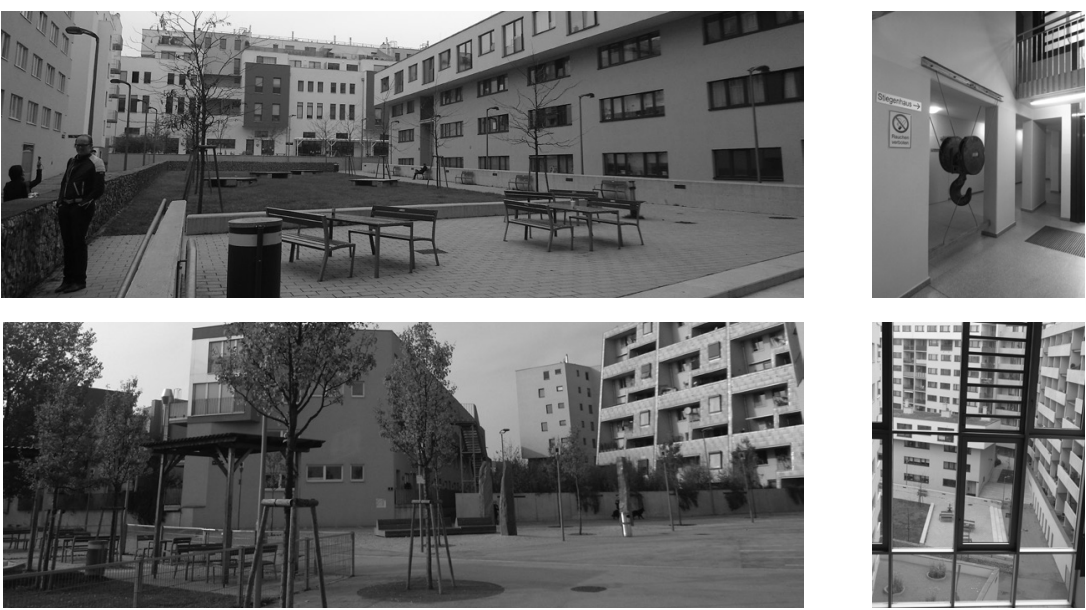
In addition to the local community, developers were also highly involved in the beginning phase of the regeneration process. However, due to the wise decision of the district authorities to prepare a document (based on local citizens' demands) to serve as a guideline for the future urban development of the district, the developers were forced to adjust their own interests to the original development vision. This was followed by a one-tier urban design competition, which was organised by the city authorities and the developers' union, with the participation of some international architectural and urban design teams. The two winners formed a joint venture for the formulation of the upcoming urban design concept, and then, for the urban design project.

\section{Organisation and management of the planning process}

The collaboration and interaction among all the stakeholders involved were carefully designed from the very beginning of the process by two groups: a Working Group and a Monitoring Group (Figure 2). The Working Group was composed of urban planning experts and consultants from the fields of transportation and landscape architecture (all from different departments of the City of Vienna), the winners of the urban design competition, and the representatives of the developers. This group was assigned the critical role of organising the discussions, information flows, control of the planning process, and finally, formulation of the urban design concept. As the Working Group progressed, the focus shifted towards the Monitoring Group, which acted as an advisory board on the findings and proposals made by the Working Group. The Monitoring Group consisted of the representatives of the local community (Citizens' Advisory Board), city government (the Mayor's Office as the Chief Executive), district authorities (various departments), and external consultants.

After the urban design concept was adopted, the "test project" phase followed. In this phase, the previously composed winning team, i.e. the joint venture, was proposing various modifications (test projects) of the urban design concept in order to ensure the initially defined vision was fulfilled. The Monitoring Group constantly provided thorough discussions to help formulate recommendations for the preparation of the urban design project, again by the winning teams. The urban design project was subject to review by the Monitoring Group and, after a series of interim discussions, the draft master plan for the KDAG area was presented to the public. After feedback was gathered, the Monitoring Group approached the city government so that its representatives could produce a final master plan. Thus, in June 2002, four years after the first idea on the possible regeneration of the KDAG site, the Regulatory Plan, produced by the Department for Urban Development of the City of Vienna, was adopted by the city government. 
Negotiation process and decision-making procedures

Thanks to a clear organisation of the planning process, the negotiation among different stakeholders was well structured. In the beginning phase, an intensive information flow and the citizens' involvement increased mutual understanding between the local community and the experts. The Citizens' Advisory Board did not participate in the formulation of the urban design concept or in the urban design project as this role was reserved for the Working Group. However, citizens were constantly able to monitor the planning process through the Citizens' Advisory Board, thus contributing to "democratic and constructive decision-making. ${ }^{\prime 32}$ Later, the members of the Working Group were convinced that the high-quality project could only have been achieved through the "bilateral agreements and process management based on teamwork." 33 Thus, each phase of the urban design process was examined in regular discussions, and all crucial decisions on the urban design concept, "test projects", and urban design project were made by the Monitoring Group.

\section{Conflict resolution}

In such a complex stakeholders' network, composed of several expert groups combined with a great citizens' impact and interwoven with developers' demands, it was not possible to collaborate without conflicts. Some of them were so strong that "it seemed the entire process was going to fail." ${ }^{34}$ This was particularly expressed by the Working Group, which was composed of members with different interest backgrounds. Nevertheless, the elimination of mutual confrontations was achieved through the sessions of the Monitoring Group. The possible conflicts with the city administration could be avoided since the political representatives were a significant part of the Monitoring Group. Also, before its final adoption, the draft of the master plan was presented to the citizens' representatives, thus ensuring the final solution was appropriate for all the direct participants in the planning process. Finally, a consensus-based master plan was the result of extensive discussions and clearly formulated demands for the quality of the urban space. The KDAG site after construction phase is presented in Figure 3-6.

\section{Former Roma settlement: Corvin, Budapest}

The former Roma settlement of Corvin (Corvin-Szigony) is located within the wider centre of Budapest and belongs to District VIII, named Jozefvaros (Józsefváros). ${ }^{35}$ Corvin covers 22 hectares and is strategically well situated: connected with the central city core, close to two subway stations, and on the corridor route leading to the airport. There was a total of 1100 social housing 


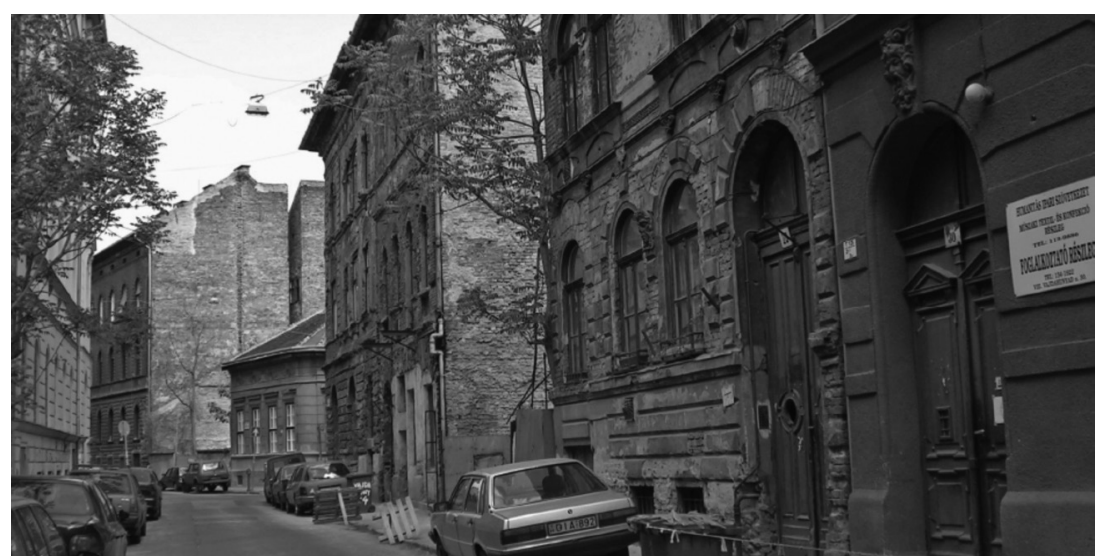

Figure 7. Roma settlement in Budapest. (Source: Author)

Initiator: DISTRICT AUTHORITY

Local Community

1/3 Roma population

(to be kept on the site)
Private sector

Futureal company

(bought the site in 2004)

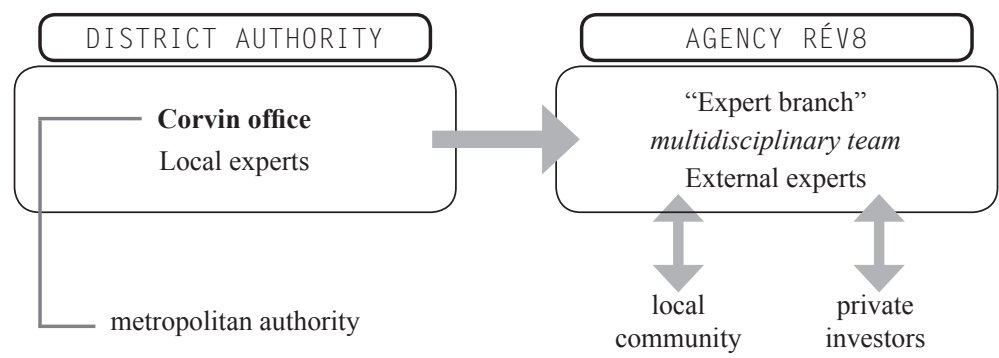

Roles:

Roles:

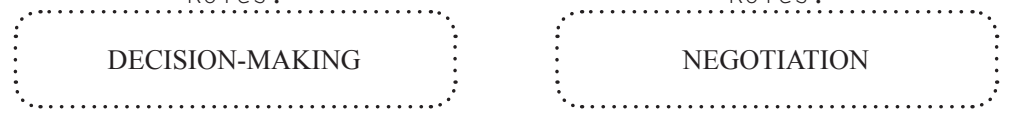

Result:

District office decision 2005

basis for the Regulatory District plan changes

Figure 8. The structure of the brownfield regeneration process in Budapest, Hungary. (Source: Author)
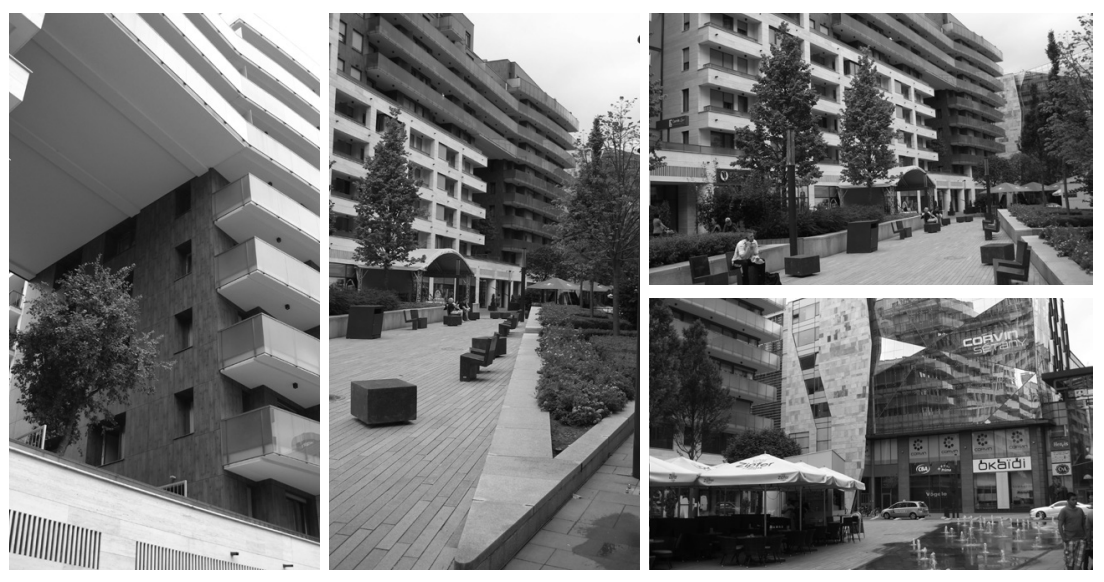

Figure 9-12. Corvin site in 2012. (Source: Author) 
units on the site in extremely poor condition, 800 of which were unacceptable for habitation and thus mainly abandoned (Figure 7). Owing to its development potential and efforts to avoid gentrification, the regeneration of the Corvin site demanded an innovative and non-standardised approach. The planning phase of the Corvin redevelopment process lasted one year, from 2004, when the private company Futureal bought the site, to 2005, when final changes in the Regulatory District Plan allowed construction to begin.

\section{Initiation of the brownfield regeneration process}

The original decision of the district administration was to keep the majority of the local population, one-third of which were the members of the Roma community, at the site or at least in District VIII or surrounding districts. Based on earlier ghettoisation, dilapidated infrastructure networks, and poor building stock, district authorities initiated a brownfield regeneration process aimed at "not only an improvement of the building stock, but also the achievement of economic, social, and cultural benefits." ${ }^{36}$ This goal required involving private investors. However, at the beginning of the redevelopment process, the private sector representatives were not reliable partners for collaboration. In fact, none of the investors were able to financially support a regeneration process in accordance with the original decision of the district to keep the majority of the local population on the site. Finally, in 2004, after two years of looking for an appropriate partner, Futureal, the largest residential construction contractor in Hungary, bought the site. The fact that the district authorities stayed decisive, i.e. they did not conform to the demands of the private sector, reveals the significance of the public sector: "their recognition of public values as well as the determination to achieve the long-term goals, instead of the short-term financial benefits pursued by private sector." ${ }^{37}$

\section{Organisation and management of the planning process}

The organisation of the planning process was assigned to Rév8 (Agency for Rehabilitation and Urban Development), considered the "expert branch" of local government, ${ }^{38}$ which was founded in 1997 by the district authorities. The agency included an interdisciplinary team of highly educated experts, thus providing not only the technical expertise in terms of making integrative strategies and policies, but also intense mediation skills between other stakeholders, particularly investors and the local community. Moreover, communication with other sectors ran smoothly because this expert sector of the local administration was strongly dedicated to the success of the Corvin regeneration project (Figure 8). More precisely, with financial support from the district authorities, local people were able to obtain a housing unit in the same 
location (Corvin) or to choose another unit in the same or neighbouring districts without paying any extra financial compensation, which was considered a "socially acceptable compromise." ${ }^{39}$ Hence, the interests of social groups with a very low power levels were protected. Also, the act of financing the allocation of original inhabitants by the district administration increased the success rate in their collaboration with the private sector.

\section{Negotiation process and decision-making procedures}

The Rév8 agency had a key negotiation role in the planning phase of the Corvin brownfield regeneration in terms of both the knowledge and skills of its members. Firstly, in relation to local society, Rév8 provided a detailed analysis of the social structure of the population, an identification of their needs, and an expert analysis of the building stock conditions of about 2500 household units. Secondly, local residents had been kept informed about new plan proposals, which is "for Hungarian standards, a very informal aspect of communication during the planning process. ${ }^{" 40}$ Moreover, through the initiative of the local NGO called Grund, the local population succeeded in preserving local values. A former gathering place of local people was recognised as a local cultural value and, with the efforts of the local community and the Rév 8 agency, investors also agreed on its importance as a bearer of the Corvin identity. In addition to negotiating with the local community, Rév8 was the mediator between the district administration and the private sector (Futureal company). However, decision-making was not within the jurisdiction of the agency, but rather in the the specific body of the district authorities - called the Corvin office. Its main role was monitoring the Rév8 agency and setting limits for each phase of the site regeneration. Specifically, at each stage of this complex process, the proposals and measures formulated by Rév 8 were forwarded to the district administration through the Corvin office.

In addition to this, the proactive role of the Corvin office, especially in maintaining the position of the public body (thus serving the public interest) is also seen in the following 'episode'. The original Regulatory District Plan of 2002 only prescribed the land for residential purposes. But in 2005, the plan had to be changed with the aim of increasing mixed-use areas based on investor demands and the agreement of the district authorities. Although for investors this was actually "a reward for a very risky investment, not only financially, but also in political terms", ${ }^{41}$ the development vision of a socially sustainable regeneration (defined at the beginning of planning process) was not compromised. In fact, owing to the experts sticking to their own principles in the design of public spaces, the investors agreed with the necessity of satisfying 
social goals through the construction of schools and health centres, job creation through employing local people in the process of building demolition and new construction, as well as in planning public open spaces.

\section{Conflict resolution}

Although originally the Rév8 agency was formed jointly by the district administration and the Budapest city administration, in the later stages of the regeneration process, communication with the city administration was not intensive. The reason for this lack of vertical collaboration is that "the mayor did not understand the need for the redevelopment of the Corvin site". ${ }^{42}$ This 'misunderstanding' brought about the need for informal procedures and innovative approaches, which resulted in changes to the previously established development priorities. More precisely, the original concept of the brownfield regeneration was conceived as a public-private partnership, which, by working with the same investment fund, should involve the private sector, local government, and the city administration of Budapest. In the end, the municipal government only donated 15 percent of the total investment, as opposed to the original one-third. As the district government was not able to fund the remaining 15 percent, the shortfall was compensated for the investors by increasing the number of housing units, compared to the number originally planned. Since the Rév 8 agency sought a sustainable solution in economic and social terms, the quality of public space was still a priority. Therefore, the realisation of the necessary capacity was provided by adding another floor, and not, for example, by constructing new facilities (Figure 9-12). This ultimately shows the power of the public sector and the skills of its representatives in the collaboration with investors. ${ }^{43}$

\section{DISCUSSION: COLLABORATIVE PLANNING PROCEDURES IN A CONCRETE PLANNING CONTEXT}

After presenting an overview of the organisation of collaborative planning processes, describing how negotiations among major stakeholders were undertaken and how conflicts were resolved, we take a closer look at the details of the planning processes in the specific spatial planning contexts of Austria and Hungary:

- Which stakeholders had a particularly important role?

- Is the cooperation among various sectors usually managed as described?

- Are the implemented procedures typical for the planning context in which they are embedded?

Brief answers to these questions are presented in the following sections. 
'Open' planning process in Vienna

The stakeholders' cooperation in the process of the KDAG site regeneration in Vienna can be characterised as "unconventional, informal and innovative." 44 This certainly describes organising a collaboration with a large number of experts with various professional profiles, local and 'external' members of the public sector and the scientific community, and the cooperation between the experts and the local community representatives. Moreover, the informality of the planning approach was supported by the relationship between the public sector representatives (in the form of the City of Vienna) and the local community. Specifically, the citizens were involved in the following actions: 1) the formulation of the preliminary proposals for the site's development, 2) choosing the best solution prepared by the architectural teams, 3) the continuous monitoring process, and 4) all the discussions leading up to the formulation of the outcomes during various phases of the planning process.

Furthermore, the KDAG factory "is officially the most successful example of brownfield regeneration in Vienna ever, confirmed by its undiminished topicality even several years after the implementation phase. ${ }^{\$ 45}$ Moreover, in recent years there were no successful examples of an unconventional planning approach to the brownfield redevelopment process. Thus, the particularity of the KDAG approach lies in the time horizon needed for both the planning and implementation phases. In particular, the entire process lasted for ten years, which is a "short period of time when taking into account the complexity of the organisation of the planning process, as well as the remediation and construction phases that followed." ${ }^{\prime 46}$

Finally, a particularity of the KDAG redevelopment process within the general planning context of Austria is that, although it has a highly decentralised power system when it comes to the topic of spatial development, ${ }^{47}$ it is not a consensus-based society to its full degree. The formal planning instruments involve informing the public about a certain spatial decisions, but they do not ensure the inclusion of the local community in the planning process. ${ }^{48}$ Hence, the active involvement of citizens in the regeneration process of the KDAG site implied the "institutionalisation of the collaborative planning approach in Austrian spatial context." ${ }^{49}$

\section{Integrative planning procedures in Budapest}

Due to the expert agency Rév8, "urban planning was understood as a management process, and not as pure technical expertise." 50 This kind of 
planning process organisation was implemented for the first time in the history of Hungarian urban planning practice at the Corvin site, and since then it has been used in other similar cases. ${ }^{51}$ Also, what makes this case special in terms of collaboration is the cooperation with civil society. The role of this sector in formulating brownfield regeneration policies is often limited and decisions are made without public debate. ${ }^{52}$ However, in the Corvin case, the less powerful stakeholders were also included, i.e. the Roma population, and the 'voices' of the civil sector, i.e. Grund, were listened to. Moreover, the investors' interests were not achieved at the expense of the interests of the local community, i.e. in addition to contributing to the local identity preservation, original inhabitants also had economic benefits, because one of the conditions of the district administration was the creation of new jobs in order to promote employment of the original inhabitants of the Corvin site.

Furthermore, even though public-private partnerships are prescribed on the local planning level, especially in the Integrated Urban Development Strategy of Budapest as the preferred mechanism for collaboration within the complex developmental process, ${ }^{53}$ there are few examples in planning practice where the guidelines actually took effect. ${ }^{54}$ However, the public-private partnership established through the Corvin regeneration is one of the "most successful examples of long-term cooperation between the public and private sectors, and as such it is recognised at European level." ${ }^{55}$

Thus, the case study of the Corvin regeneration clearly shows a tendency towards consensus-based and polycentric (in terms of different power centres) policy-making. Namely, the Regulatory District Plan resulted from the "collaboration among the most important stakeholders from public, private and civil sectors." ${ }^{56}$ Hence, the redevelopment of the Corvin site should be understood as a forerunner of institutional transformation, i.e. as a "preferred way of urban policy formulation, not only in Budapest, but in all of Hungary." 57 In other words, the Corvin revitalisation "signals institutional reforms towards integrative and holistic brownfield regeneration." 58

\section{CONCLUDING REMARKS:}

TOWARDS A CHANGE IN THE PLANNING CULTURE

In the end, it is interesting once again to briefly summarise the role of local governance in the brownfield regeneration process as well as its relationship with other relevant stakeholders. 
In the Viennese case study, the critical role throughout the entire process of brownfield regeneration was assigned to the City of Vienna. This body was responsible for starting the regeneration project, playing a key role in the efficient organisation of the planning process, and making key decisions. The particularity of the Viennese approach to brownfield regeneration is seen in the great appreciation of local needs, demands and wishes for the further improvement of the area. Keeping in mind the role of the local community in creating the identity of the space, and the democratic context of decisionmaking in Austria, such a collaborative approach could not only take place here, but could also produce a long-term positive effect on the development of the neighbouring areas.

In Budapest, the major role in the brownfield regeneration of the Corvin site was appointed to the district administration. Its representatives initiated the process, played the crucial role of mediator between the developers and the local community, and were responsible for all the decisions made as a means to influence further implementation of the planning proposals. In contrast to the Viennese case study within which the district authority had the full support by the City of Vienna, the metropolitan authorities in Budapest did not share the same vision for the future development of the Corvin site. Thus, the private investors had a major role in the regeneration process. Nevertheless, such a public-private collaboration needs to be highly coordinated. This leads us to the following conclusions.

In both case studies, the success factor for the brownfield regeneration process was in the close collaboration between local governance and the experts. In other words, there is a clear need for the integration of experts and decisionmaking power.

Viennese expert representatives of the city government played a critical role throughout the entire brownfield regeneration process. In addition to their technical expertise, they were greatly involved in the collaboration with developers in order to find feasible solutions for both parties (public and private); and, they were focused on raising the awareness of various benefits of brownfield regeneration for local population. In addition, based on the outcome, their mediating role with other experts (both local and external) should not be neglected.

In Budapest, the district authority's decision, which directly determined the success of the entire regeneration process, was to establish its own expert body - the Rév8 agency. As district authorities within the metropolitan administration 
system have both the power to create and implement various policies in the field of spatial development, and must react quickly in adjusting their own developmental priorities to the general market trends, the resolution to create their own expert unit had a positive effect on the cooperation among all the stakeholders: it ran smoothly.

Collaborative planning procedures are useful tools when it comes to complex spatial problems such as brownfield regeneration. Since a collaborative planning paradigm is the dominant planning doctrine nowadays, it is not surprising that similar planning procedures are appearing in different planning cultures. For both case studies, the following initiatives were the key to success:

1. Involvement of the public sector, which provided objectivity and comprehensiveness in the planning process.

2. The planning expertise comprised both broad knowledge and skills. This actually changed the planning process management, thus making both formal and informal planning compatible.

Formal planning instruments and planning systems can only be affected by strengthening informal planning procedures. Hence, new planning approaches are the mechanism for the Europeanisation of spatial planning policy-making. Nevertheless, if new planning approaches to complex spatial problems are really to contribute to a change in planning culture, there is a need for a stable society. In fact, the problem of brownfield regeneration should be understood as an expert task aimed at achieving long-term development. It should not be 'just' a political question or a market demand. In years to come, Serbian society will testify if some of the successful European planning approaches to brownfield regeneration have served as ideas for the redefinition of the planning culture in Serbia.

NOTES

1

See: David Adams and Craig Watkins, Greenfields, Brownfields and Housing Development (Oxford: Blackwell Publishing, 2002); Tim Dixon et al., Sustainable Brownfield Regeneration: Liveable Places from Problem Spaces (Chichester, GBR: Wiley, 2008); Joseph W. Dorsey, "Brownfields and Greenfields: The Intersection of Sustainable Development and Environmental Stewardship," Environmental Practice 5 (2003); Detlef Grimski and Uwe Ferber, "Urban brownfields in Europe," Land Contamination \& Reclamation 9 (2001).

Sandra Alker et al., "The Definition of Brownfield," Journal of Environmental Planning and Management 43 (2000): 49.

The brownfield regeneration cycle includes also land remediation, building, and operationalisation phase. See: Rolf Kettler and Kaarina Schenk, "Brownfield-Recycling in Switzerland: eliminating contaminated sites and re-using derelict land at the same time," in Proceedings of the second international conference on Managing Urban Land (Stuttgart, Germany, April 25-27, 2007). (Dessau: Federal Environment Agency Germany, 2007).

Patsy Healey, "Re-thinking Key Dimensions of Strategic Spatial Planning: Sustainability and Complexity," in Fuzzy Planning: The Role of Actors in a Fuzzy Governance Environment, eds. Gert de Roo and Geoff Porter. (Abingdon, Oxon, GBR: Ashgate Publishing Group, 2007). 
Ana Perić, "Uloga urbanističkog planiranja u procesu regeneracije braunfild lokacija / The Role of Urban Planning in the Process of Brownfield Regeneration" (PhD diss., University of Belgrade, 2013).

See: Yaakov Garb and Jirina Jackson, "Brownfields in the Czech Republic 1989-2009: The long path to integrated land management," Journal of Urban Regeneration and Renewal 3 (2010): 276; Tim Dixon and Joe Doak, "Actors and drivers: Who and what makes the brownfield regeneration process go round?" (paper presented at the SUBR:IM Conference, Sheffield, UK, March 1, 2005); David E. Booher and Judith E. Innes, "Network Power in Collaborative Planning," Journal of Planning Education and Research 21 (2002); Yvonne Rydin, "Re-Examining the Role of Knowledge Within Planning Theory," Planning Theory 6 (2007).

See: Ana Perić and Marija Maruna, "Predstavnici društvene akcije u procesu regeneracije priobalja - slučaj braunfild lokacije 'Luka Beograd' / The Representatives of Social Action in Waterfront Regeneration - the Case of the Brownfield Site 'Belgrade Port”), “ Sociologija i prostor 192 (2012); Ana Perić and Marija Maruna, "Brownfield Regeneration versus Greenfield Investment - Is Serbia on the Way to Integrated Land Management?" Journal of Urban Regeneration and Renewal 6 (2012).

The participants in brownfield regeneration process, among others, are: land-leasers, land-owners, developers, investors, communal companies, governmental agencies, local authority, agencies for environmental protection, local community, visitors of the area, construction companies, real estate agents, engineers, and architects. See: Dixon and Doak, "Actors and drivers".

See: Dixon and Doak, "Actors and drivers"; Dixon et al., Sustainable Brownfield Regeneration; Alker et al., "The Definition of Brownfield".

See: Jesse D. Silverstein, "Mechanics' of the Deal: Assembling the Brownfields Team," Environmental Practice 5 (2003); Michael R. Thomas, "Brownfield Redevelopment: Information Issues and the Affected Public," Environmental Practice 5 (2003); Dixon et al., Sustainable Brownfield Regeneration; Garb and Jackson, "Brownfields in the Czech Republic 1989-2009".

Perić, "Uloga urbanističkog planiranja u procesu regeneracije braunfild lokacija", 8.

Silverstein, "'Mechanics' of the Deal”.

Nikos Karadimitriou, Joe Doak and Elisabete Cidre, "Rethinking Brownfields: Discourses, Networks and Space-Time," in New Directions in Planning Theory: Planner's Encounter with Complexity, eds. Gert de Roo and Elisabete A. Silva. (Abingdon, Oxon, GBR: Ashgate Publishing Group, 2010).

Silverstein, “'Mechanics' of the Deal”.

According to Jürgen Habermas, the interest is any permanent motive for action, just as important as the other two central concepts derived from the general 'phenomenon of life' - information and values. Interests are based on needs, and can originate from a value preference, while not necessarily meaning on the material, but also on other interests. Interests are basically embedded in the process of social structuring and, for the social management, of utmost importance are legitimate, i.e. socially acceptable interests. See: Miodrag Vujošević, Racionalnost, legitimitet $i$ implementacija planskih odluka: Novije teorijske interpretacije i pouke za planiranje u tranziciji (Beograd: Institut za arhitekturu i urbanizam Srbije, 2004).

The values are the elements of consciousness that connects many normative expectations, i.e. the value represents a combination of norms and interests. Values are more durable than the normative imperative and interest engagement, but may be also more volatile that is influenced by the tension between the value in their normative meaning and actual everyday interests of the people. In terms of planning, the most important role of value is that of a criterion, which influence the actions of different actors in the planning interaction. See: Vujošević, Racionalnost, legitimitet $i$ implementacija planskih odluka.

Consensus can be defined as follows: "The degree to which different actors and agencies share the value system and goals and who are therefore more or less willing to perform certain policies and programmes". See: Susan Barrett and Colin Fudge, Policy and Action: essays on the implementation of public policy (London: Methuen, 1981). Other authors see a consensus as a means for reducing 
the degree of uncertainty in the planning process, especially in the case of a large number of actors with diverse interests. See: Gert de Roo, "Shifts in Planning Practice and Theory: From a Functional towards Communicative Rationale," in Fuzzy Planning: The Role of Actors in a Fuzzy Governance Environment, eds. Gert de Roo and Geoff Porter. (Abingdon, Oxon, GBR: Ashgate Publishing Group, 2007), 110.

Patsy Healey, Collaborative Planning - Shaping places in fragmented societies (London: MacMillan Press, 1997), 219.

Ibid, 263-264.

Healey, "Sustainability and Complexity".

The power can be defined as the ability of an actor to achieve his own will, even at the expense of other participants in the same (planning) process. In fact, the power is the relationship between the desires and a final outcome. The ratio between the power and influence can be explained as follows: directed power is a form of general social influence, while the other form of influence is an undirected (system) power, i.e. structural influence, which actually comes from the characteristics of the socio-economic system. See: Tore Sager, Communicative Planning Theory (Aldershot: Averbury, 1994).

Healey, Collaborative Planning, 287.

Ibid, 288-289.

Ibid, 298.

Herbert Buchner, Rudolf Kohoutek and Volkmar Pamer, Kabelwerk - A Development Process as a Model: The State of the Art (Vienna: City of Vienna, 2004).

Krisztina Keresztély and James W. Scott, "Urban Regeneration in the Post-Socialist Context: Budapest and the Search for a Social Dimension,” European Planning Studies 20 (2012), 11111134.

In Vienna, the interview was conducted with Volkmar Pamer, the representative of the city government - the chief of the Department for Urban Development of the City of Vienna, who actively participated and monitored the entire brownfield regeneration process (both planning and implementation phase), as a member of the Working Group. For the Hungarian case study, two interviewees were selected: György Molnár, scientific collaborator of the Economic Institute of the Hungarian Academy of Science, a member of the local governance of VIII district until 2011, and György Alföldi, the director of the expert agency Rév8 (Rehabilitációs és Városfejlesztési Zrt). Both interviewees were actively involved in various phases of the brownfield regeneration process of the Corvin site.

Michael Q. Patton, Qualitative Evaluation \& Research Methods (Newbury Park: Sage Publications, 1990).

The municipality of Vienna consists of 23 districts. However, they do not possess any administrative power. By constitution, Vienna is a statutory city and, thus, a single administrative unit. See: Iván Tosics, National spatial planning policies and governance typology (PLUREL Deliverable Report 2.2.1), accessed May 25, 2011, http://www.plurel.net.

Buchner, Kohoutek and Pamer, Kabelwerk.

Volkmar Pamer, interview by Ana Perić, Vienna, November 6, 2011.

Ibid.

Ibid.

Ibid.

Budapest is specific due to its two-tier governance, i.e. metropolitan and district level. There are 23 districts within the metropolitan region of Budapest, each of which with its independent responsibilities in the domain of district urban development. See: Keresztély and Scott, "Urban Regeneration in the Post-Socialist Context".

György Alföldi, interview by Ana Perić, Budapest, July 24, 2012.

György Molnár, interview by Ana Perić, Budapest, July 24, 2012.

Ibid.

Alföldi, interview. 
Ibid.

Molnár, interview.

Ibid.

Ibid.

Pamer, interview.

The organisation of the planning process was awarded twice by the renowned reward in the field of urban development (Otto Wagner Urban Development Prize) - in 2001 and in 2004, i.e. at the beginning of the implementation phase. See: Buchner, Kohoutek and Pamer, Kabelwerk.

Ibid.

In Austria, there is no federal act on spatial planning valid for the entire country. In fact, the states (German: Länder) are responsible for the legislation in the field of spatial planning and development. Thus, there are in total nine spatial planning laws in Austria (according to the number of states). Finally, state authorities control the implementation of the planning policies at the local governance level. See: Alexander Hamedinger, "The changing organisation of spatial planning in Vienna: learning lessons from the organisation of planning in the UK in the context of the shift from government to governance?" (paper presented at the EURA/UUA Conference: City Futures, Chicago, US, July 8-10, 2004).

STEP 05 - Urban Development Plan Vienna (Vienna: Stadtentwicklung Wien, 2005)

Ibid.

Alföldi, interview.

Ibid.

Keresztély and Scott, "Urban Regeneration in the Post-Socialist Context".

Mart Grisel and Frans van de Waart, eds. Multilevel Urban Governance or the Art of Working Together-Methods, Instruments and Practices (The Hague: European Urban Knowledge Network, 2011).

Keresztély and Scott, "Urban Regeneration in the Post-Socialist Context".

Molnár, interview. Moreover, in 2014, the Corvin Promenade project was awarded by the ULI (Urban Land Institute) Global Award for Excellence. See: "Corvin Promenade received an award", EpiteszForum, accessed July 14, 2015, http://epiteszforum.hu/ujabb-dijat-kapott-a-corvin-setany. Ibid; Alföldi, interview.

Molnár, interview.

Alföldi, interview.

Adams, David, and Craig Watkins. Greenfields, Brownfields and Housing Development. Oxford: Blackwell Publishing, 2002.

Alker, Sandra, Victoria Joy, Peter Roberts, and Nathan Smith. "The Definition of Brownfield." Journal of Environmental Planning and Management 43 (2000): 49-69.

Barrett, Susan, and Colin Fudge. Policy and Action: essays on the implementation of public policy. London: Methuen, 1981.

Booher, David E., and Judith E. Innes. "Network Power in Collaborative Planning" Journal of Planning Education and Research 21 (2002): 221-236.

Buchner, Herbert, Rudolf Kohoutek, and Volkmar Pamer. Kabelwerk - A Development Process as a Model: The State of the Art. Vienna: City of Vienna, 2004.

de Roo, Gert. "Shifts in Planning Practice and Theory: From a Functional Towards Communicative Rationale." In Fuzzy Planning: The Role of Actors in a Fuzzy Governance Environment, edited by Gert de Roo, and Geoff Porter, 103-114. Abingdon, Oxon, GBR: Ashgate Publishing Group, 2007.

Dixon, Tim, and Joe Doak. "Actors and drivers: Who and what makes the brownfield regeneration process go round?” Paper presented at the SUBR:IM Conference, Sheffield, UK, March 1, 2005.

Dixon, Tim, Mike Raco, Philip Catney, and David N. Lerner. Sustainable Brownfield Regeneration: Liveable Places from Problem Spaces. Chichester, GBR: Wiley, 2008.

Dorsey, Joseph W. "Brownfields and Greenfields: The Intersection of Sustainable Development and Environmental Stewardship.” Environmental Practice 5 (2003): 69-76. 
EpiteszForum. "Corvin Promenade received an award." Accessed September 14, 2015. http:// epiteszforum.hu/ujabb-dijat-kapott-a-corvin-setany.

Garb, Yaakov, and Jirina Jackson. "Brownfields in the Czech Republic 1989-2009: The long path to integrated land management." Journal of Urban Regeneration and Renewal 3 (2010): 263-276.

Grimski, Detlef, and Uwe Ferber. "Urban brownfieds in Europe." Land Contamination \& Reclamation 9 (2001): 143-148.

Grisel, Mart, and Frans van de Waart, eds. Multilevel Urban Governance or the Art of Working Together - Methods, Instruments and Practices. The Hague: European Urban Knowledge Network, 2011.

Hamedinger, Alexander. "The changing organisation of spatial planning in Vienna: learning lessons from the organisation of planning in the UK in the context of the shift from government to governance?" Paper presented at the EURA/UUA Conference: City Futures, Chicago, US, July $8-10,2004$.

Healey, Patsy. Collaborative Planning - Shaping places in fragmented societies. London: MacMillan Press, 1997.

Healey, Patsy. "Re-thinking Key Dimensions of Strategic Spatial Planning: Sustainability and Complexity." In Fuzzy Planning: The Role of Actors in a Fuzzy Governance Environment, edited by Gert de Roo, and Geoff Porter, 21-41. Abingdon, Oxon, GBR: Ashgate Publishing Group, 2007.

Karadimitriou, Nikos, Joe Doak, and Elisabete Cidre. "Rethinking Brownfields: Discourses, Networks and Space-Time." In New Directions in Planning Theory: Planner's Encounter with Complexity, edited by Gert de Roo, and Elisabete A. Silva, 263-281. Abingdon, Oxon, GBR: Ashgate Publishing Group, 2010.

Keresztély, Krisztina., and James W. Scott. "Urban Regeneration in the Post-Socialist Context: Budapest and the Search for a Social Dimension.” European Planning Studies 20 (2012): 11111134.

Kettler, Rolf, and Kaarina Schenk. "Brownfield-Recycling in Switzerland: eliminating contaminated sites and re-using derelict land at the same time." In Proceedings of the second international conference on Managing Urban Land (Stuttgart, Germany, April 25-27, 2007), 41-46. Dessau: Federal Environment Agency Germany, 2007.

Patton, Michael Q. Qualitative Evaluation \& Research Methods. Newbury Park: Sage Publications, 1990.

Perić, Ana. "Uloga urbanističkog planiranja u procesu regeneracije braunfild lokacija / The Role of Urban Planning in the Process of Brownfield Regeneration.” PhD diss., University of Belgrade, 2013.

Perić, Ana, and Marija Maruna. "Predstavnici društvene akcije u procesu regeneracije priobalja slučaj braunfild lokacije 'Luka Beograd' / The Representatives of Social Action in Waterfront Regeneration - the Case of the Brownfield Site 'Belgrade Port'." Sociologija i prostor 192 (2012): $61-88$.

Perić, Ana, and Marija Maruna. "Brownfield Regeneration versus Greenfield Investment - Is Serbia on the Way to Integrated Land Management?" Journal of Urban Regeneration and Renewal 6 (2012): 79-90.

Rydin, Yvonne. "Re-Examining the Role of Knowledge within Planning Theory." Planning Theory 6 (2007): 52-68.

Sager, Tore. Communicative Planning Theory. Aldershot: Averbury, 1994.

Silverstein, Jesse D. "“Mechanics' of the Deal: Assembling the Brownfields Team.” Environmental Practice 5 (2003): 53-57.

STEP 05 - Urban Development Plan Vienna. Vienna: Stadtentwicklung Wien, 2005.

Thomas, Michael R. "Brownfield Redevelopment: Information Issues and the Affected Public." Environmental Practice 5 (2003): 62-68.

Tosics, Iván. National spatial planning policies and governance typology (PLUREL Deliverable Report 2.2.1). Accessed May 25, 2011. http://www.plurel.net.

Vujošević, Miodrag. Racionalnost, legitimitet i implementacija planskih odluka: Novije teorijske interpretacije i pouke za planiranje u tranziciji. Beograd: Institut za arhitekturu i urbanizam Srbije, 2004.

World Bank. The Management of Brownfields Redevelopment - A Guidance Note. Washington DC: World Bank, 2010. 


\section{ULOGA LOKALNE UPRAVE U PROCESU REGENERACIJE BRAUNFILD LOKACIJA: EVROPSKA PLANERSKA PRAKSA \\ Ana Perić}

Pošto mnogobrojni učesnici sa različitim interesima u procesu braunfild regeneracije povećavaju složenost samog procesa, zanimljivo je posmatrati prirodu njihove saradnje. Fokus ovog rada je na ulozi lokalnih vlasti kao jednom od ključnih stejkholdera odgovornih za uspeh braunfild regeneracije. Položaj kao i instrumenti koje koristi lokalna uprava u datom procesu mogu se rasvetliti kroz posmatranje organizacije planskog procesa, pregovaračkih i procedura donošenja odluka, kao i načina rešavanja konflikata. Empirijski istraživački okvir ovog rada čine dve evropske studije slučaja braunfild regeneracije: nekadašnja fabrika kablova i žica u Beču i bivše romsko naselje u Budimpešti. Rad daje uvid u mogućnosti za redefinisanje planske kulture kroz inovativne i proaktivne planske pristupe braunfild regeneraciji.

KLJUČNE REČI: REGENERACIJA BRAUNFILDA, LOKALNA UPRAVA, KOLABORACIJA, BEČ, BUDIMPEŠTA

\section{LOKALNA UPRAVA, DRUŠTVENO-PROSTORNI RAZVOJ I SEGREGACIJA U POST-TRANZICIONOJ MAĐARSKOJ \\ Nora Teller}

Svedoci smo ponovnog skaliranja koncepta upravljanja u Zapadnoj Evropi poslednjih 25 godina. U ovom radu se daje pregled literature o pojavama koje se odnose na promene u upravljanju urbanim planiranjem izazvane uticajem neoliberalnog režima, i naglašavaju se paralelna pitanja u kontekstu post-tranzicione Mađarske. Izazovi lokalne samouprave su diskutovani kroz prizmu mehanizama koji su podstakli segregaciju u mađarskom urbanom kontekstu. U radu se zaključuje da je glokalizacija, podstaknuta nedavno razvijenim politikama rešavanja problema urbane nejednakosti i segregacije finansiranim iz fondova EU, glavni ishod decentralizacije javne uprave u Mađarskoj. Međutim, jednim delom neki od pokušaja urbane rehabilitacije su zasnovani na 'disekonomijama sukoba', što ukazuje da rezultati mogu postati neodrživi u budućnosti.

\section{KAPACITET “GLOKALNOG” UPRAVLJANJA: RUDARSKO NASLEĐE SARDINIJE}

\section{Nađa Beretić, Arnaldo Bibo Cecchini, Zoran Đukanović, Alessandro Plaisant}

Rad se bavi istraživanjem kapaciteta upravljanja rudnim industrijskim nasleđem Sardinije. Rudarska kultura Sardinije datira iz perioda od pre 8 hiljada godina, gde je oduvek predstavljala industrijski razvojni motor regiona, ugašena je '60-ih godina prošlog veka, a kasnije, 1997. godine, proglašena od strane UNESCO-a za nasleđe od izuzetnog značaja. Danas, ovi predeli se odlikuju izrazitom depopulacijom, i nedovoljnim kapacitetima upravljanja i rukovođenja; pejzaži izuzetne lepote imaju karakter osmišljenih, ali polu-doživljenih i pseudo-živih mesta. Istraživanje je pragmatične orijentacije, sa kvalititativnim karakterom; orijentisano da utvrdi šta i kako treba raditi u odnosu na željenu budućnost. Ono je multidisciplinarnog pristupa i uvek podrazumeva istraživanje u određenom društvenom, istorijskom, ekonomskom i političkom kontekstu.

Ispitivanje trendova i urbanih potencijala sardinijske teritorije rađeno je u komparaciji sa savremenom evropskom strategijom. Istraživanje govori o "zajedničkom kulturnom iskustvu" kao dugoročnoj komponenti održivosti, koja počiva, zasnovana je i pokreće se, na nivou lokalne zajednice.

Glavno pitanje rada razmatra "Glokalnu", lokalnu i globalnu, sposobnost upravljanja pomoću "ose partnerstva” (lokalni nivo - Parco Geominerario Storico e Ambientale - evropska i globalna mreža geoparkova - UNESKO), kao prve komponente kreativnog partnerstva, koja vodi ka integrisanju lokalne zajednice u participativni, kulturni, proces ponovnog razvoja, u kontekstu sardinijskog rudnog nasleđa kao održivog dizajna ovog sistema. 